\title{
Cuprobismutite group minerals (cuprobismutite, hodrušhite, kupčíkite and paděraite), other Bi-sulfosalts and Bi-tellurides from the Obari mine, Yamagata Prefecture, Japan
}

\author{
Yuya Izumino*, Kazuo NAKASHima ${ }^{* *}$ and Mariko NagaShima ${ }^{* * *}$ \\ *Graduate School of Science and Engineering Yamagata University, Kojirakawa 1-4-12, Yamagata 990-8560, Japan \\ ** Department of Earth and Environmental Sciences, Yamagata University, Kojirakawa 1-4-12, Yamagata 990-8560, Japan \\ ${ }^{* * *}$ Graduate School of Science and Engineering, Yamaguchi University, Yoshida 1677-1, Yamaguchi 753-8512, Japan
}

\begin{abstract}
Cuprobismutite group minerals have been discovered for the first time in Japan from the Obari mine, Yamagata Prefecture. Furthermore, many kinds of $\mathrm{Bi}$-sulfosalts and $\mathrm{Bi}$-tellurides have been found from this mine. $\mathrm{Cu}-$ probismutite occurs as irregular particles which are intergrown with makovickyite. The empirical formula of cuprobismutite is $\left(\mathrm{Cu}_{7.71} \mathrm{Fe}_{0.41}\right)_{\sum 8.12}\left(\mathrm{Bi}_{12.17} \mathrm{Ag}_{1.57} \mathrm{~Pb}_{0.07} \mathrm{Sb}_{0.07}\right)_{\sum 13.88}\left(\mathrm{~S}_{23.95} \mathrm{Se}_{0.06}\right)_{\sum 24.01}$ (based on total atoms = 46). Hodrušhite, kupčíkite and paděraite occur as euhedral to subhedral blade-shaped crystals with parallel intergrowth. The empirical formulae of these minerals are $\left(\mathrm{Cu}_{7.64} \mathrm{Fe}_{0.36}\right)_{\sum 8.00}\left(\mathrm{Bi}_{11.18} \mathrm{Cu}_{0.35} \mathrm{Ag}_{0.26} \mathrm{~Pb}_{0.07} \mathrm{Sb}_{0.07}\right)_{\sum 11.93}$ $\left(\mathrm{S}_{21.98} \mathrm{Se}_{0.09}\right)_{\sum 22.07}$ (based on total atoms $\left.=42\right),\left(\mathrm{Cu}_{3.56} \mathrm{Fe}_{0.50} \mathrm{Zn}_{0.04}\right)_{\sum 4.10}\left(\mathrm{Bi}_{4.84} \mathrm{Sb}_{0.03}\right)_{\sum 4.87}\left(\mathrm{~S}_{10.00} \mathrm{Se}_{0.03}\right)_{\sum 10.03}$ (based on total atoms $=19)$ and $\mathrm{Cu}_{7.00}\left[\left(\mathrm{Cu}_{0.50} \mathrm{Ag}_{0.17}\right)_{\sum 0.67} \mathrm{~Pb}_{1.27} \mathrm{Bi}_{11.01} \mathrm{Sb}_{0.05}\right]_{\Sigma 13.00}\left(\mathrm{~S}_{21.91} \mathrm{Se}_{0.09}\right)_{\sum 22.00}$ (based on total atoms $=42)$ for hodrušhite, kupčíkite and paderaite, respectively. The content of trace elements $(\mathrm{Ag}, \mathrm{Fe}$ and $\mathrm{Pb}$ ) in each cuprobismutite group mineral is consistent with the characteristics shown by previous works.
\end{abstract}

Keywords: Cuprobismutite, Hodrušhite, Kupčíkite, Paděraite, Obari mine

\section{INTRODUCTION}

The Obari mine, located in Tsuruoka City, Yamagata Prefecture, Japan is famous in the country as a high-grade Bi-deposit. This mine is also known for the occurrence of Bi-sulfosalts such as aikinite (Takaoka, 1969) and wittichenite (Watanabe, 1937, 1938a, 1938b, 1938c, 1951, Sugaki et al., 1974), however for a long time, the other Bi-sulfosalts have not been studied in detail. Recently, makovickyite and cupromakovickyite were discovered during a re-investigation of Bi-bearing ores from the mine (Izumino et al., 2013). Moreover, the crystal structure of makovickyite from this mine was studied in detail by Nagashima et al. (2013). During these studies, we have found many kinds of $\mathrm{Bi}$-sulfosalts and Bi-tellurides including cuprobismutite group minerals (cuprobismutite, hodrušhite, kupčíkite and paděraite) for the first time

doi: $10.2465 /$ jmps. 140129

Y. Izumino, s13e101d@st.yamagata-u.ac.jp

K. Nakashima,nakashi@sci.kj.yamagata-u.ac.jp Corresponding author

M. Nagashima, nagashima@yamaguchi-u.ac.jp in Japan. This paper mainly deals with the mode of occurrence and chemistry of the cuprobismutite group minerals as well as other Bi-sulfosalts and Bi-tellurides.

Cuprobismutite group minerals, belonging to sulfosalts of $\mathrm{Cu}-\mathrm{Bi}-\mathrm{S}$ systems, have been classified into cuprobismutite homologous minerals (cuprobisumutite, hodrušhite and kupčíkite) and paděraite as a species related to the series (Makovicky, 1989). The former is represented by the general formula, $\mathrm{Cu}_{4} \mathrm{M}_{2(\mathrm{~N}-1)+1} \mathrm{Bi}_{4} \mathrm{~S}_{2 \mathrm{~N}+8}$, where $\mathrm{M}$ is Bi and $\mathrm{Ag}$ (Makovicky, 1989). Cuprobismutite with an ideal formula of $\mathrm{Cu}_{8} \mathrm{AgBi}_{13} \mathrm{~S}_{24}$, is the most major mineral of cuprobismutite group minerals and was first described from the Missouri deposit, USA (Hillebrand, 1884). Hodrušhite with an ideal formula of $\mathrm{Cu}_{8} \mathrm{Bi}_{12} \mathrm{~S}_{22}$, often occurs in the world and was first reported from the Banská Hodruša, Romania (Koděra et al., 1970). Kupčíkite with an ideal formula of $\mathrm{Cu}_{3.4} \mathrm{Fe}_{0.6} \mathrm{Bi}_{5} \mathrm{~S}_{10}$, is a rare mineral and the newest mineral of the four, and was discovered from the Felbertal deposit, Austria (Topa et al., 2003b). Paděraite with an ideal formula of $\mathrm{Cu}_{7}[(\mathrm{Cu}$, $\left.\mathrm{Ag})_{\Sigma 0.33} \mathrm{~Pb}_{1.33} \mathrm{Bi}_{11.33}\right]_{\Sigma 13} \mathrm{~S}_{22}$, is a rare mineral and was found in Băita Bihor, Romania for the first time (Mumme 
and Žák, 1985). The crystal structures of all these minerals were refined by Topa et al. (2003a) and Topa and Makovicky (2006). The group minerals mainly consist of $\mathrm{Cu}, \mathrm{Bi}$ and $\mathrm{S}$, with minor components ( $\mathrm{Fe}, \mathrm{Ag}$ and $\mathrm{Pb}$ ), maintaining the charge balance. In general, cuprobismutite contains significant amounts of Ag, hodrušhite includes small amounts of $\mathrm{Fe}$ and $\mathrm{Ag}$, kupčíkite has a high content of $\mathrm{Fe}$, and paděraite contains substantial amounts of $\mathrm{Pb}$. The crystal structure analyses of the minerals indicated interdependent substitutions such as (1) $\mathrm{Cu} \leftrightarrow \mathrm{Bi}$, (2) $\mathrm{Ag} \leftrightarrow \mathrm{Bi}$, (3) $\mathrm{Pb} \leftrightarrow \mathrm{Bi}$ and (4) $\mathrm{Fe} \leftrightarrow \mathrm{Cu}$ (Topa et al, 2003a: Topa and Makovicky, 2006).

\section{GEOLOGICAL SETTING}

Late Cretaceous-Paleogene granitoids are distributed in the studied area and most of the granitoids belong to the ilmenite series (Ishihara et al., 1983). The geology around the Obari mine is composed of Cretaceous Tagawa acidic rocks, Cretaceous to Paleogene Wasada granodiorite and Neogene sedimentary rocks of the Oizumi formation (Fig. 1). Tagawa acidic rocks consist of dacitic pyroclastic rocks and granodiorite porphyry, and are partly metamorphosed by the intrusion of the Wasada granodiorite (Yauchi et al., 1973). The Wasada granodiorite belongs to exceptionally the magnetite series, and has

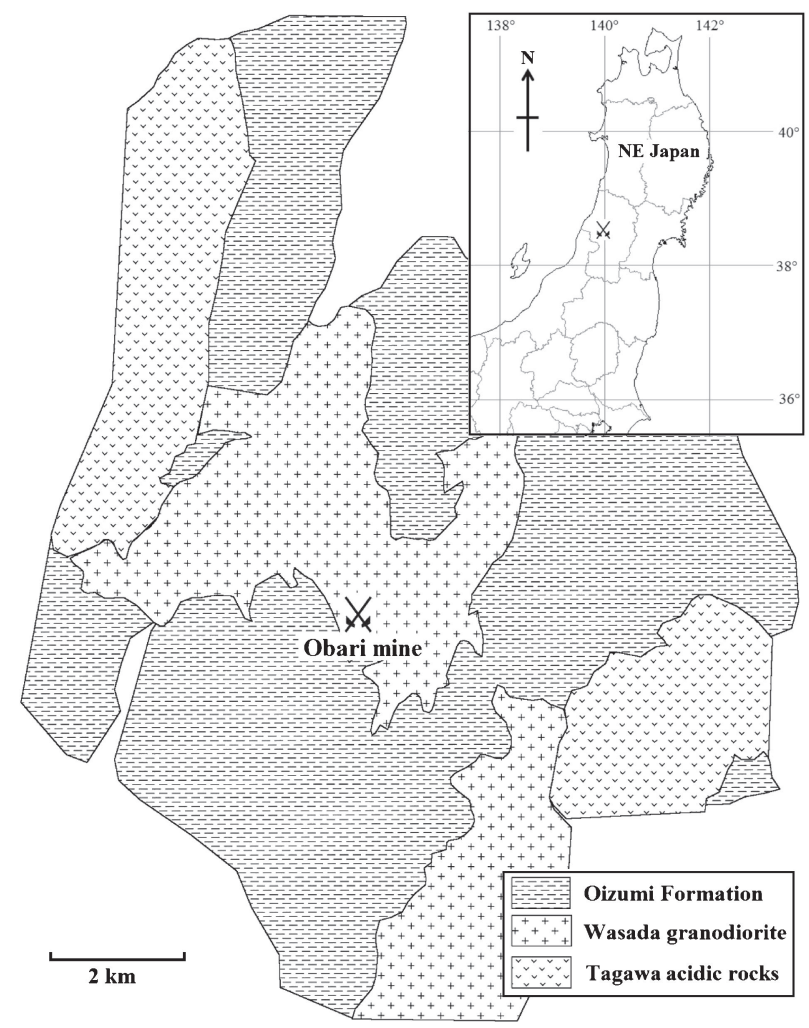

Figure 1. Geological map of the Obari mine area (modified after Shimazu et al., 1961). many $\mathrm{Au}-\mathrm{Ag}-\mathrm{Cu}-\mathrm{Pb}-\mathrm{Zn}-\mathrm{Bi}-\mathrm{Mo}$ deposits in and around the granitic body. The Obari mine is the largest ore deposit in this region. This mineralization is related to the Wasada granodiorite (Agency of Natural Resources and Energy, 1982). The Oizumi Formation consists of volcanic pyroclastic rocks and volcanic rocks, and is widely distributed in covering unconformably the Tagawa acidic rocks and Wasada granodiorite (Agency of Natural Resources and Energy, 1982).

The Obari mine is an $\mathrm{Au}-\mathrm{Cu}-\mathrm{Bi}$ dissemination vein type deposit which is altered along the fissure in the Wasada granodiorite and was mined during 1936-1966. The dissemination vein is characterized by potassic alteration (Takaoka, 1969), and K-feldspar, muscovite and quartz were formed in the altered host rock. Main ore minerals are chalcopyrite, tetrahedrite and $\mathrm{Bi}^{-}$-sulfosalts, and are disseminated in the gangue minerals. The grade of ore, Au: 200 g/t, Ag: 150-500 g/t, Cu: 10-15\%, Bi: 3-8\% (Shimazu et al., 1961), indicates that the Bi concentration is much higher than in other Bi deposits in Japan.

\section{ORE MINERALOGY}

Ore samples used in this study were obtained by a former employee of the Obari mine. Ore minerals composed of the specimens are $\mathrm{Bi}$-sulfosalts, Bi-tellurides, chalcopyrite, pyrite, sphalerite, galena, tetrahedrite, tennantite, bornite, arsenopyrite, molybdenite, electrum and hessite. Gangue minerals are quartz, muscovite, K-feldspar, albite, rutile, anatase, brookite, apatite and zircon. Among the ore minerals except for $\mathrm{Bi}$ minerals, chalcopyrite is the most common mineral in this mine. The mineral occurs as massive aggregates and often coexists with aikinite (Fig. 2a) and wittichenite (Fig. 2b). Bornite is closely associated with chalcopyrite, and includes lamellae of chalcopyrite and wittichenite (Fig. 2c). Tetrahedrite-tennantite repleces crystals of chalcopyrite (Fig. 2d) and bornite. Sphalerite sometimes occurs in chalcopyrite and contains chalcopyrite dots in the grains. Galena is closely associated with cosalite and aikinite. Electrum occurs as small inclusions in aikinite and chalcopyrite (Fig. 2e). Arsenopytite and pyrite show euhedral crystals and are partly replaced by chalcopyrite. Molybdenite disseminates as small tabular crystals in chalcopyrite. Hessite rarely occurs as small inclusions within wittichenite.

$\mathrm{Bi}$-sulfosalts and Bi-tellurides discovered in this study are cuprobismutite group minerals (cuprobismutite, hodrušhite, kupčíkite and paděraite), makovickyite, cupromakovickyite, wittichenite, emplectite, miharaite, aikinite-bismuthinite series (aikinite, friedrichite, hammarite, lindströmite, krupkaite, pekoite and bismuthinite), galenobismutite, cannizzarite, cosalite, lillianite, nuffiel- 

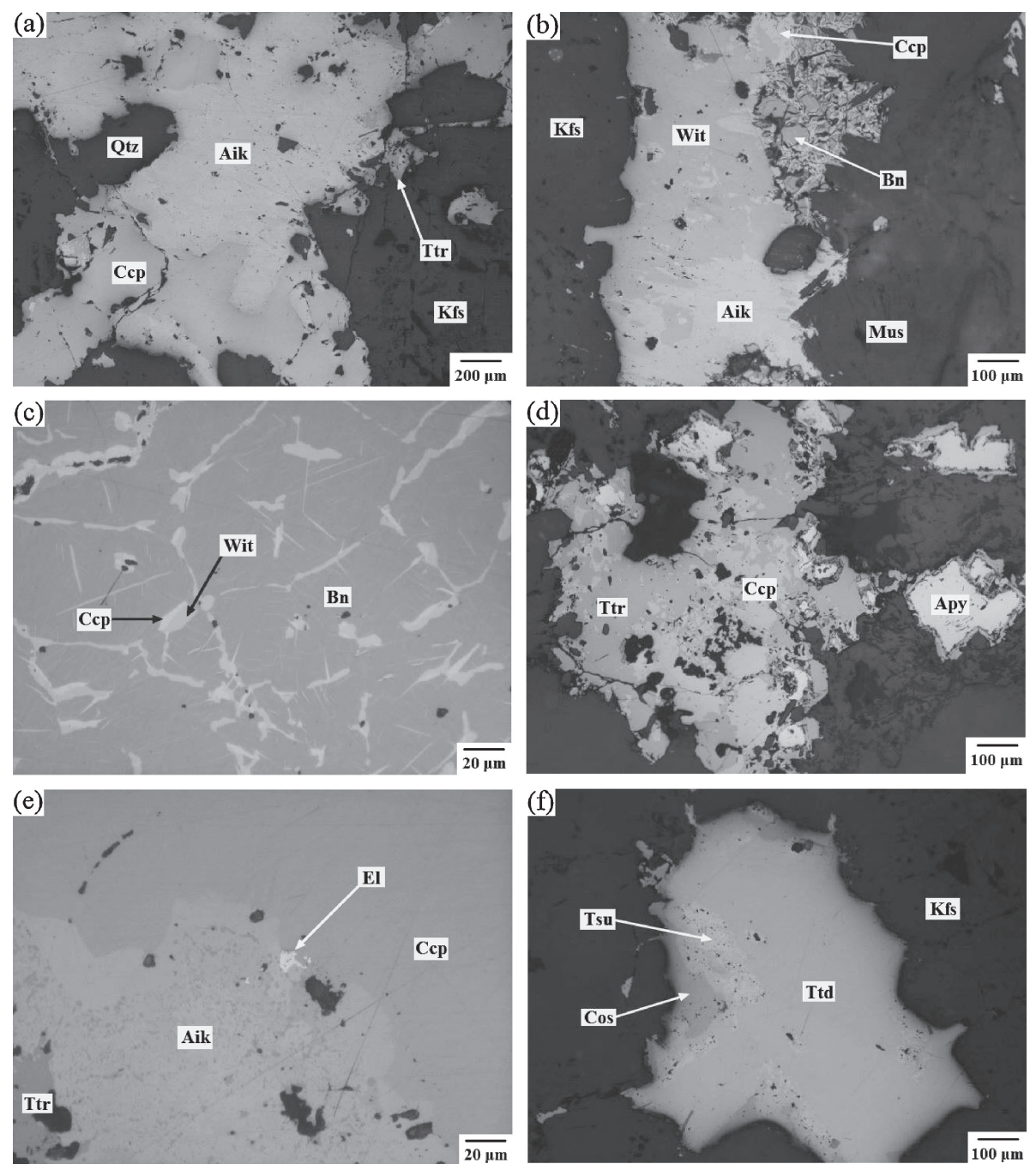

Figure 2. Photomicrographs of the mineral assemblage in the Obari mine: (a) Associations of aikinite (Aik), chalcopyrite (Ccp) and tetrahedrite (Ttr). (b) Associations of aikinite, wittichenite (Wit), chalcopyrite and bornite (Bn). (c) The eutectic intergrowths of bornitechalcopyrite-wittichenite. (d) Chalcopyrite replaced by tetrahedrite and euhedral crystals of arsenopyrite (Apy). (e) Small inclusions of electrum (El) in aikinite and chalcopyrite. (f) Tabular crystal of tetradymite (Ttd) associated with tsumoite (Tsu) and cosalite (Cos). Color version is available online from http://japanlinkcenter.org/ DN/JST.JSTAGE/jmps/140129.

dite, tellurobismuthite, tsumoite, tetradymite, joséite-B, and rucklidgeite. In addition to these minerals, native $\mathrm{Bi}$ and secondary minerals such as bismutite occur in the ores. Makovickyite and cupromakovickyite have been described in detail by Izumino et al. (2013).

\section{METHOD}

Chemical analyses were carried out using a JEOL JXA8600S wavelength dispersive electron microprobe at the Faculty of Science, Yamagata University. Analytical conditions for quantitative analysis are accelerating voltage, $20 \mathrm{kV}$; sample current, $20 \mathrm{nA}$; beam diameter, $3 \mu \mathrm{m}$, and correction, ZAF. The standards used were $\mathrm{CuFeS}_{2}(\mathrm{Cu} K \alpha, \mathrm{Fe} K \alpha$ and $\mathrm{S} K \alpha), \mathrm{GaAs}$ (As $\left.L \alpha\right), \mathrm{Ag}$ $(\mathrm{Ag} L \alpha), \mathrm{Sb}_{2} \mathrm{~S}_{3}(\mathrm{Sb} L \alpha), \mathrm{ZnS}(\mathrm{ZnK} \alpha), \mathrm{PbS}(\mathrm{Pb} M \alpha), \mathrm{Cd}$ $(\mathrm{Cd} L \alpha), \mathrm{Bi}(\mathrm{Bi} L \alpha), \mathrm{Se}(\mathrm{Se} L \alpha)$ and $\mathrm{Te}(\mathrm{Te} L \alpha)$. Standard deviations (error in $\mathrm{wt} \%$ ) of elements for the cuprobismutite group minerals are: $\mathrm{Ag} 0.05, \mathrm{Cu} 0.11, \mathrm{Fe} 0.05, \mathrm{~Pb}$
0.05, Bi 0.69, Sb 0.04, Se 0.04 and S 0.08. The results of EPMA analyses of $\mathrm{Bi}$-sulfosalts and $\mathrm{Bi}$-tellurides are plotted on the ternary diagrams (Fig. 3) and are presented in Table 1. The cuprobismutite group minerals are too small and too closely associated with each other to be identified using X-ray diffraction.

To distinguish between cosalite and neyite, X-ray diffraction data on single crystals of cosalite were collected using a Bruker SMART APEX II CCD diffractometer installed at the University of Bern, Switzerland. A crystal of cosalite was mounted on a glass fiber and intensity data was measured at room temperature using graphitemonochromatized MoK $\alpha$ radiation $(\lambda=0.71069 \AA)$. Preliminary lattice parameters and an orientation matrix were obtained from twelve sets of frames and refined during the integration process of the intensity data. Diffraction data were collected with $\omega$ scans at different $\varphi$ settings ( $\varphi-\omega$ scan) (Bruker, 1999). Data were processed using SAINT (Bruker, 1999). 
(a)
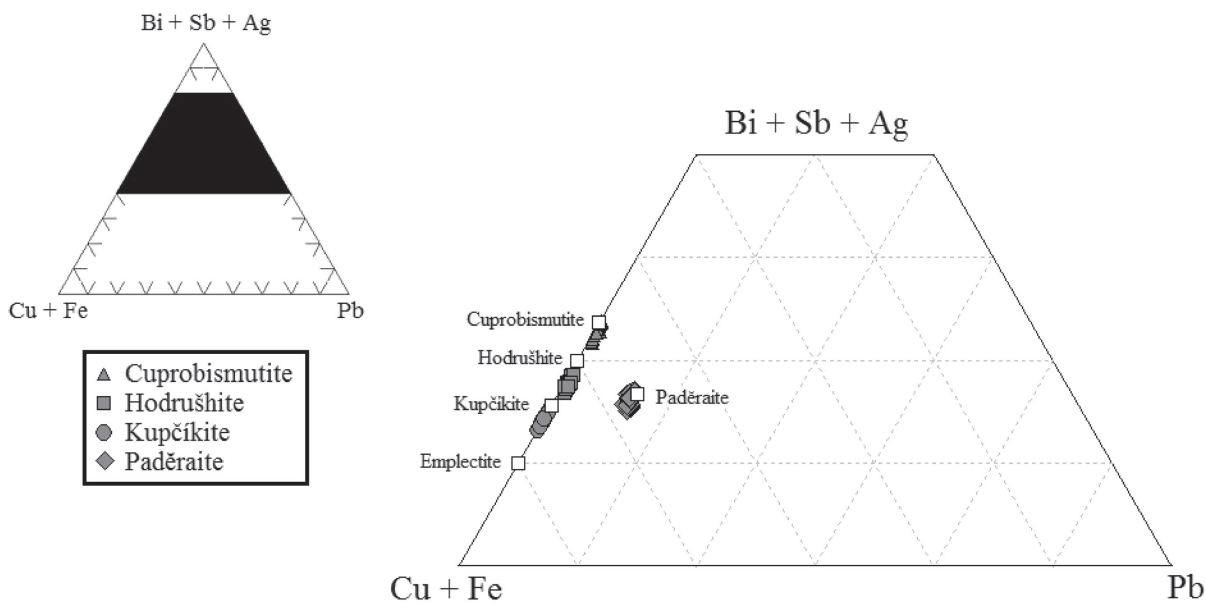

(b)

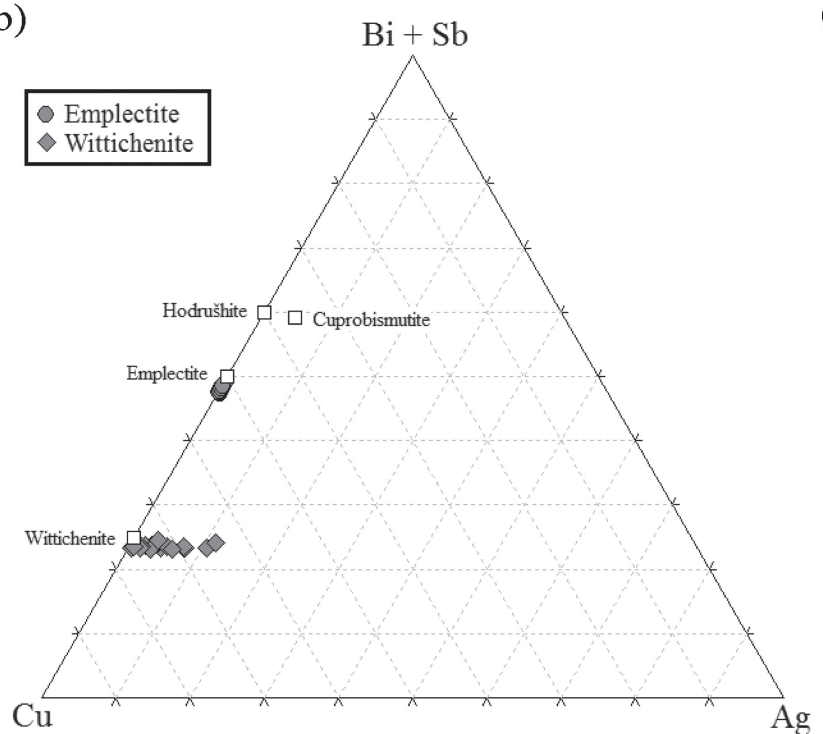

(d)

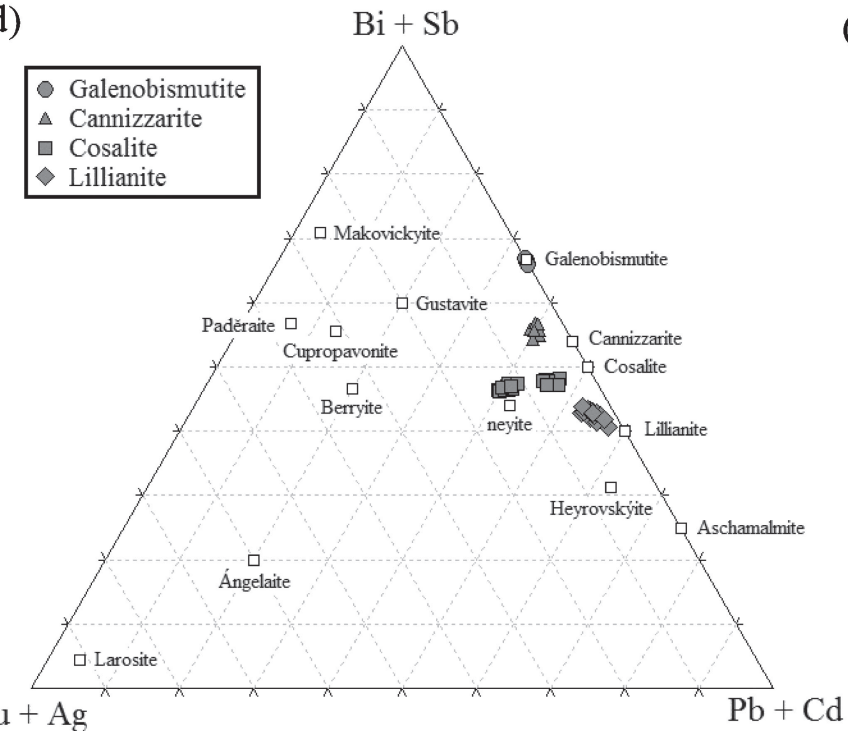

(c)

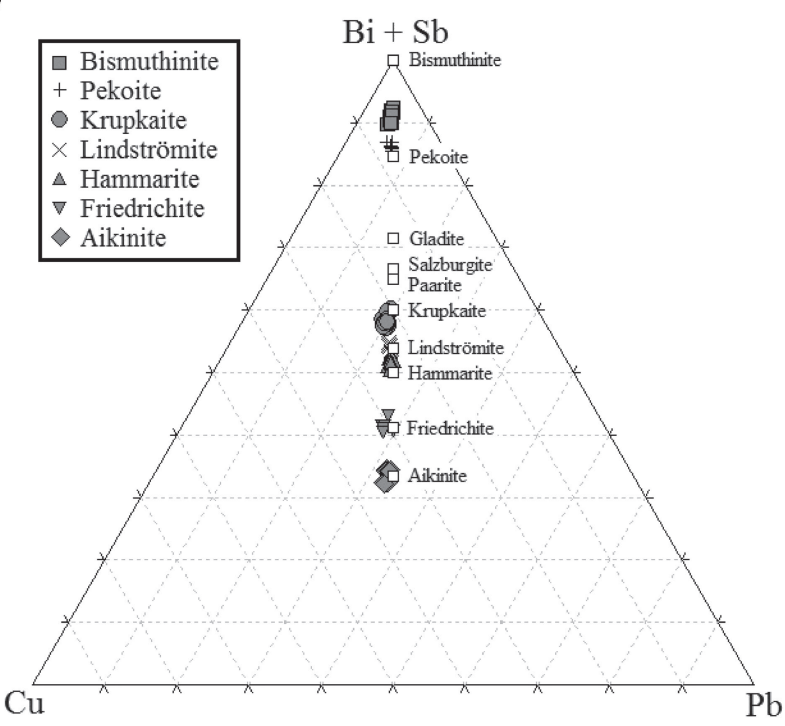

(e)

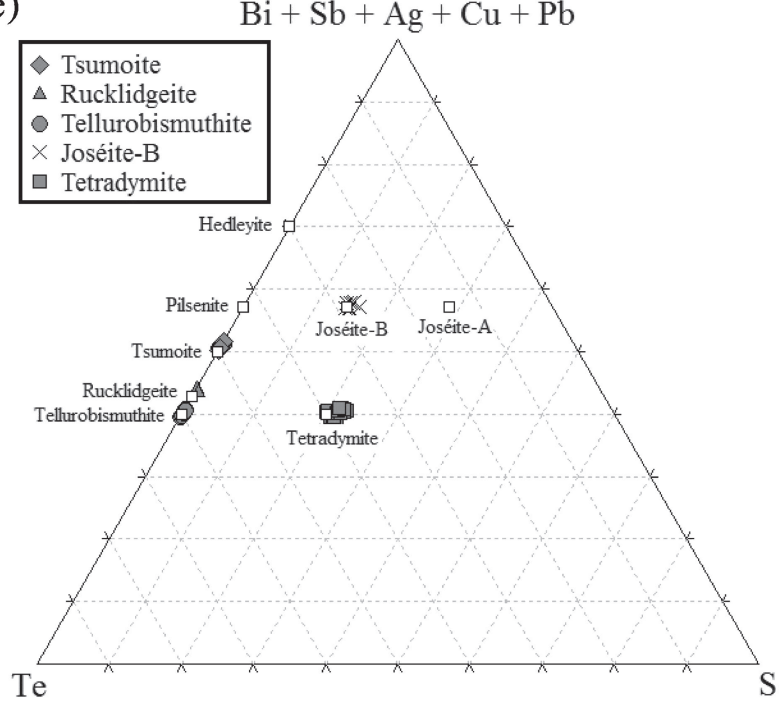

Figure 3. Ternary diagrams of Bi-sulfosalts and Bi-tellurides: (a) Cuprobismutite group minerals, (b) $\mathrm{Cu}$-Bi-S minerals, (c) Aikinie-bismuthinite series, (d) $\mathrm{Pb}-\mathrm{Bi}-\mathrm{S}$ minerals and (e) Bi-tellurides. 


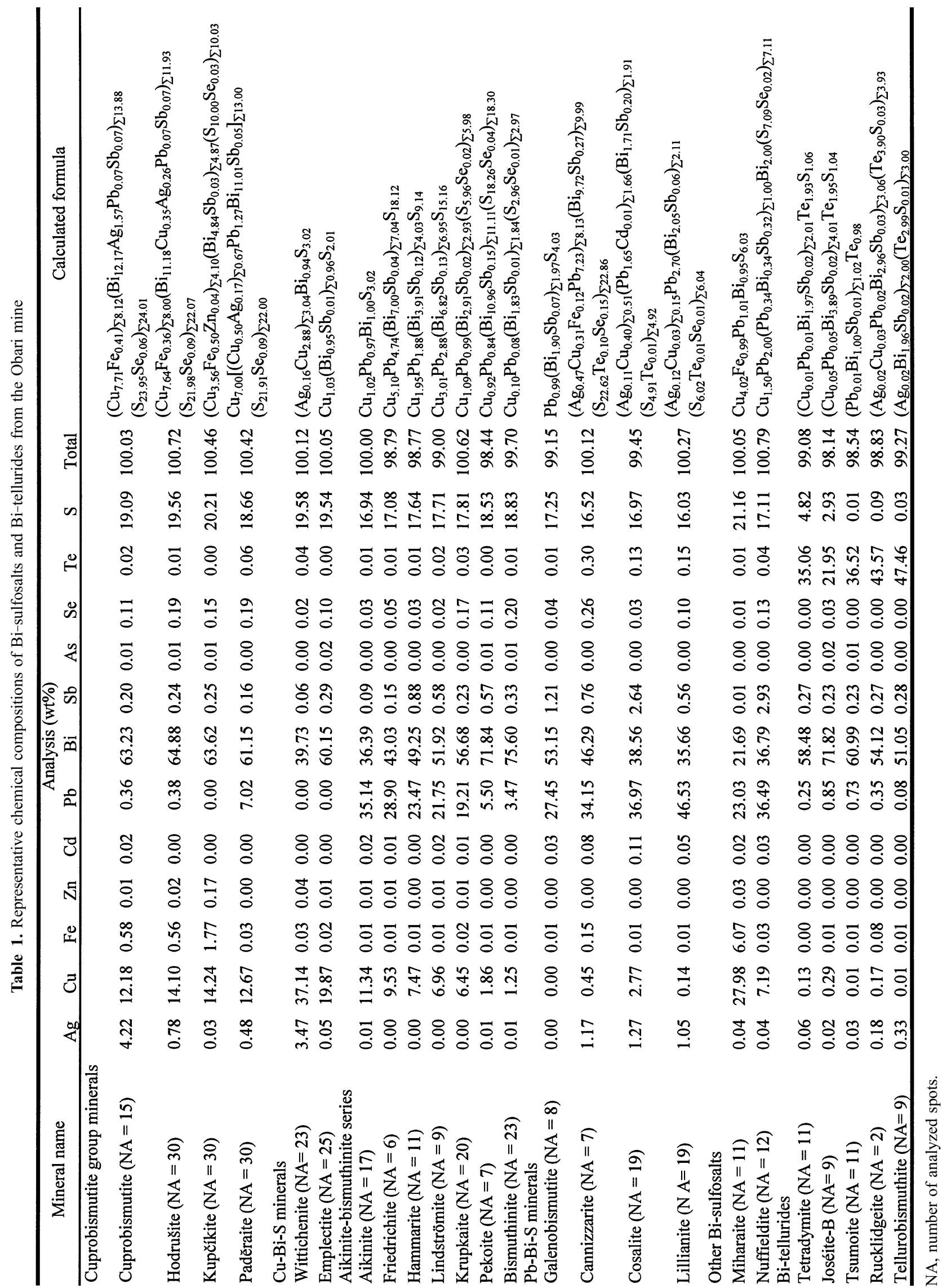




\section{MODE OF OCCURRENCE AND CHEMICAL COMPOSITION}

\section{Cuprobismutite group minerals}

Cuprobismutite is the rarest mineral of the cuprobismutite group minerals in the Obari mine, and occurs as irregular particles of 10 to $20 \mu \mathrm{m}$, and is intergrown with makovickyite and a $\mathrm{Fe}$-bearing undetermined secondary $\mathrm{Bi}^{-}$ mineral (Fig. 4a). This mineral does not coexist with other cuprobismutite group minerals. The empirical formula of the mineral is $\left(\mathrm{Cu}_{7.71} \mathrm{Fe}_{0.41}\right)_{\sum 8.12}\left(\mathrm{Bi}_{12.17} \mathrm{Ag}_{1.57} \mathrm{~Pb}_{0.07}\right.$ $\left.\mathrm{Sb}_{0.07}\right)_{\sum 13.88}\left(\mathrm{~S}_{23.95} \mathrm{Se}_{0.06}\right)_{\sum 24.01}$ (based on total atoms $=$ $46)$, corresponding to the ideal formula $\left(\mathrm{Cu}_{8} \mathrm{AgBi}_{13} \mathrm{~S}_{24}\right)$. The chemically determined value of $\mathrm{N}$ varies between 1.77 and 2.06 (average: 1.92, ideally: 2). It contains significant amounts of $\mathrm{Ag}$, small amounts of $\mathrm{Fe}$ and trace amounts of $\mathrm{Pb}, \mathrm{Sb}$ and $\mathrm{Se}$, and is rich in $\mathrm{Cu}$ and $\mathrm{Fe}$ and poor in Bi (Fig. 3a).

Hodrušhite, kupčíkite and paděraite occur as euhedral to subhedral blade-shaped crystals with parallel intergrowth, and are accompanied by makovickyite, bismuthinite, krupkaite and emplectite (Figs. 4b, 4c and 4d). This occurrence is characteristic for cuprobismutite group minerals and has been reported from other localities such as the Paulus mine, Romania (Cook and Ciobanu, 2003). Hodrušhite is $10-250 \mu \mathrm{m}$ in length and 5-30 $\mu \mathrm{m}$ in width. The empirical formula of the mineral is $\left(\mathrm{Cu}_{7.64} \mathrm{Fe}_{0.36}\right)_{\sum 8.00}\left(\mathrm{Bi}_{11.18} \mathrm{Cu}_{0.35} \mathrm{Ag}_{0.26} \mathrm{~Pb}_{0.07} \mathrm{Sb}_{0.07}\right)_{\sum 11.93}\left(\mathrm{~S}_{21.98}\right.$ $\left.\mathrm{Se}_{0.09}\right)_{\sum 22.07}$ (based on total atoms $=42$ ), corresponding to the ideal formula $\left(\mathrm{Cu}_{8} \mathrm{Bi}_{12} \mathrm{~S}_{22}\right)$. The chemically calculated $\mathrm{N}$ ranges between 1.20 and 1.39 (average: 1.27 , ideally: 1.5). This mineral has small amounts of $\mathrm{Ag}$ and $\mathrm{Fe}$ and trace amounts of $\mathrm{Pb}, \mathrm{Sb}$ and $\mathrm{Se}$, and is rich in $\mathrm{Bi}$ and poor in $\mathrm{Cu}$ (Fig. 3a). Kupčíkite is $5-50 \mu \mathrm{m}$ in length and 1-10 $\mu \mathrm{m}$ in width. The empirical formula of the mineral is $\left(\mathrm{Cu}_{3.56} \mathrm{Fe}_{0.50} \mathrm{Zn}_{0.04}\right)_{\sum 4.10}\left(\mathrm{Bi}_{4.84} \mathrm{Sb}_{0.03}\right)_{\sum 4.87}\left(\mathrm{~S}_{10.00} \mathrm{Se}_{0.03}\right)_{\sum 10.03}$ (based on total atoms $=19$ ), corresponding to the ideal formula $\left(\mathrm{Cu}_{3.4} \mathrm{Fe}_{0.6} \mathrm{Bi}_{5} \mathrm{~S}_{10}\right)$. The chemically calculated $\mathrm{N}$ has values from 0.78 to 0.98 (average: 0.88 , ideally: 1 ). It contains significant amounts of $\mathrm{Fe}$ and trace amounts of $\mathrm{Zn}, \mathrm{Sb}$ and $\mathrm{Se}$, and is rich in $\mathrm{Cu}, \mathrm{Fe}$ and $\mathrm{Zn}$ and poor in Bi (Fig. 3a). Paděraite is $10-100 \mu \mathrm{m}$ in length and $1-20 \mu \mathrm{m}$ in width. The empirical formula of the mineral is $\mathrm{Cu}_{7.00}\left[\left(\mathrm{Cu}_{0.50} \mathrm{Ag}_{0.17}\right)_{\sum 0.67} \mathrm{~Pb}_{1.27} \mathrm{Bi}_{11.01} \mathrm{Sb}_{0.05}\right]_{\sum 13.00}\left(\mathrm{~S}_{21.91}\right.$ $\left.\mathrm{Se}_{0.09}\right)_{\sum 22.00}$ (based on total atoms $=42$ ), corresponding to the ideal formula $\left(\mathrm{Cu}_{7}\left[(\mathrm{Cu}, \mathrm{Ag})_{\sum 0.33} \mathrm{~Pb}_{1.33} \mathrm{Bi}_{11.33}\right]_{\sum 13} \mathrm{~S}_{22}\right)$. This mineral has high contents of $\mathrm{Pb}$ and small contents of $\mathrm{Ag}, \mathrm{Sb}$ and $\mathrm{Se}$, and is rich in $\mathrm{Cu}$ and poor in $\mathrm{Bi}$ (Fig. 3a). Each mineral can be distinguished using X-ray intensity mapping (Fig. 5) and the BSE images (Figs. 4c and $4 d$ ). In particular, hodrušhite, kupčíkite and paděraite are distinguished by the difference in their minor components $(\mathrm{Ag}, \mathrm{Fe}$ and $\mathrm{Pb})$ of these minerals in X-ray intensity mapping (Fig. 5). Therefore, hodrušhite contains small amounts of $\mathrm{Fe}$ and $\mathrm{Ag}$, kupčíkite is the richest in $\mathrm{Fe}$ and paderraite has the highest $\mathrm{Pb}$ content.

\section{Cu-Bi-S minerals}

Wittichenite, the most common Bi-sulfosalt in the Obari mine, occurs as anhedral crystals of 0.1 to $3.0 \mathrm{~mm}$ in size, intergrown with aikinite, bornite, chalcopyrite and tetrahedrite (Fig. 2b). The eutectic intergrowths of bornitechalcopyrite-wittichenite are observed in the studied samples (Fig. 2c), which have been studied by Watanabe (1938c), Sugaki (1949a), and Sugaki (1949b). The empirical formula is $\left(\mathrm{Ag}_{0.16} \mathrm{Cu}_{2.88}\right)_{\sum 3.04} \mathrm{Bi}_{0.94} \mathrm{~S}_{3.02}$ (based on total atoms $=7)$, corresponding to the ideal formula $\left(\mathrm{Cu}_{3}\right.$ $\mathrm{BiS}_{3}$ ). This mineral contains significant amounts of $\mathrm{Ag}$, up to $14.7 \mathrm{wt} \%$, instead of $\mathrm{Cu}$ (Fig. 3b).

Emplectite occurs as irregular grains from 60 to 300 $\mu \mathrm{m}$ in size, coexisting with wittichenite and aikinite, with cuprobismutite group minerals and aikinite-bismuthinite series (Figs. 4b-4d) and with paděraite and aikinite. This mineral replaces cuprobismutite group minerals and the aikinite-bismuthinite series. The empirical formula is $\mathrm{Cu}_{1.03}\left(\mathrm{Bi}_{0.95} \mathrm{Sb}_{0.01}\right)_{\sum 0.96} \mathrm{~S}_{2.01}$ (based on total atoms $=4$ ), corresponding to the ideal formula $\left(\mathrm{CuBiS}_{2}\right)$.

\section{Aikinite-bismuthinite series}

Aikinite, the second most common $\mathrm{Bi}$-sulfosalt in the $\mathrm{Ob}$ ari mine, is widely seen, however, except for aikinite, the occurrences of the aikinite-bismuthinite series are rare. This mineral occurs as large anhedral crystals of 0.1 to $7 \mathrm{~mm}$ in size, accompanied by wittichenite, cosalite, chalcopyrite, bornite and tetrahedrite (Figs. 2a and 2b). The empirical formula is $\mathrm{Cu}_{1.02} \mathrm{~Pb}_{0.97} \mathrm{Bi}_{1.00} \mathrm{~S}_{3.02}$ (based on total atoms $=6)$, corresponding to the ideal formula $(\mathrm{CuPb}$ $\left.\mathrm{BiS}_{3}\right)$.

Friedrichite, hammarite and lindströmite occur as irregular grains at the rim of cosalite and galenobismutite (Fig. 4e). These minerals are not homogeneous and their compositions are dispersed around each ideal formula. The empirical formulae of these minerals are $\mathrm{Cu}_{5.10} \mathrm{~Pb}_{4.74}$ $\left(\mathrm{Bi}_{7.00} \mathrm{Sb}_{0.04}\right)_{\sum 7.04} \mathrm{~S}_{18.12}$ (based on total atoms $=35$ ) for friedrichite, $\mathrm{Cu}_{1.95} \mathrm{~Pb}_{1.88}\left(\mathrm{Bi}_{3.91} \mathrm{Sb}_{0.12}\right)_{\sum 4.03} \mathrm{~S}_{9.14}$ (based on total atoms $=17)$ for hammarite and $\mathrm{Cu}_{3.01} \mathrm{~Pb}_{2.88}\left(\mathrm{Bi}_{6.82}\right.$ $\left.\mathrm{Sb}_{0.13}\right)_{\sum 6.95} \mathrm{~S}_{15.16}$ (based on total atoms $=28$ ) for lindströmite, respectively (Fig. 3c).

Krupkaite occurs as irregular particles from 10 to $100 \mu \mathrm{m}$ in size at the boundary between bismuthinite and makovickyite (Fig. 4c). The empirical formula is $\mathrm{Cu}_{1.09}$ 

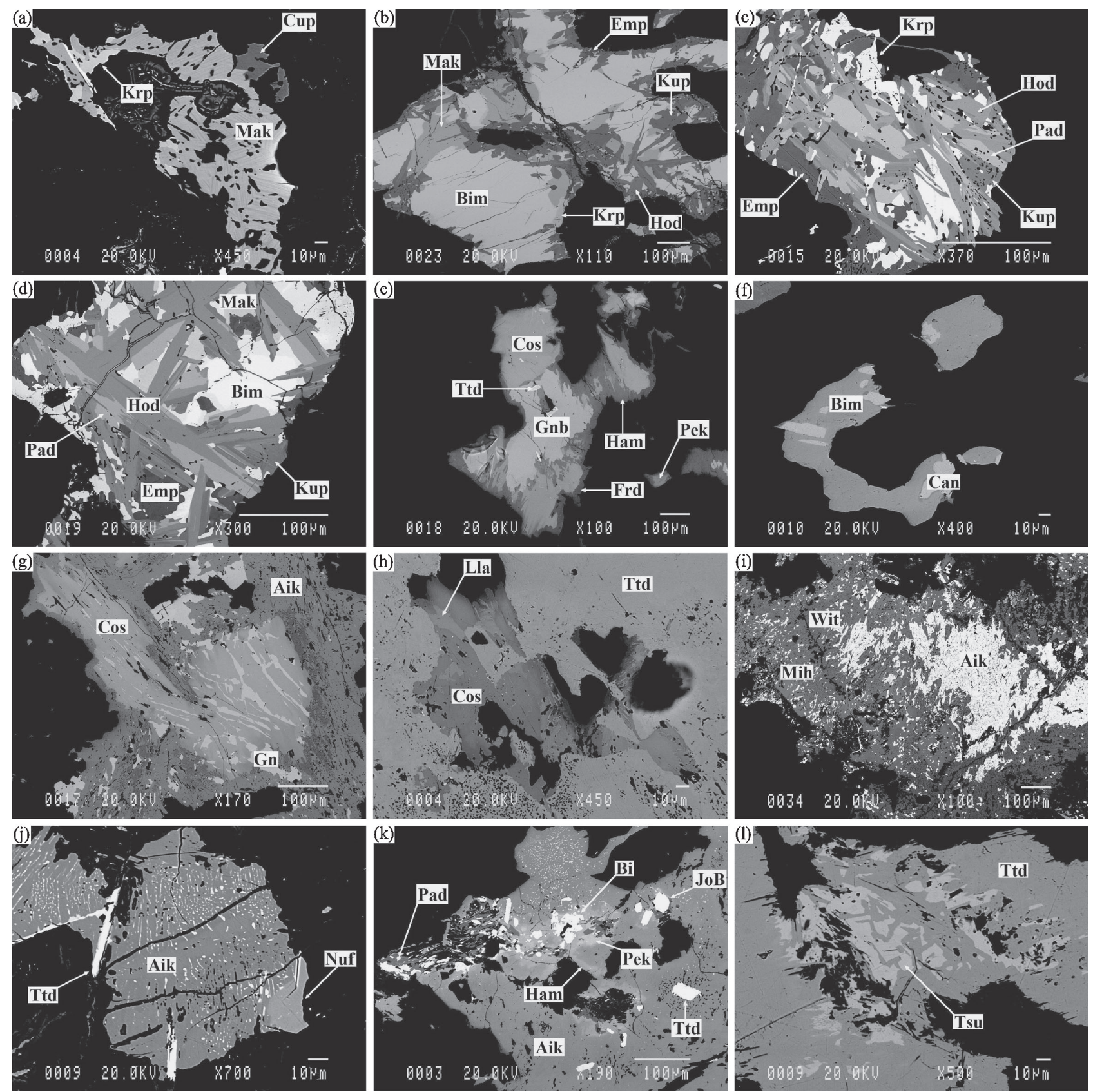

Figure 4. BSE images of Bi-sulfosalts and Bi-tellurides in the Obari mine: (a) Cuprobismutite (Cup) grains associated with makovickyite (Mak) and krupkaite (Krp). (b) Associations of bismuthinite (Bim), krupkaite, makovickyite, hodrušhite (Hod), kupčíkite (Kup) and emplectite (Emp). (c) The lamella intergrowths of hodrušhite, kupčíkite and padĕraite (Pad), in association with krupkaite and emplectite. (d) The lamellae intergrowths of hodrušhite, kupčíkite and paděraite, in association with bismuthinite, makovickyite and emplectite. (e) Aggregates of galenobismutite (Gnb), cosalite, freidrichite (Frd), hammarite (Ham) and pekoite (Pek). (f) Cannizzarite (Can) grains within bismuthinite. (g) Intergrowths of aikinite, cosalite and galena (Gn). (h) Intergrowths of lillianite (Lla) and cosalite within tetradymite. (i) Miharaite (Mih) in association with aikinite and wittichenite. (j) Nuffieldite (Nuf) grains associated with aikinite. (k) Aggregates of aikinite, tetradymite, joséite- $\mathrm{B}(\mathrm{JoB})$, native $\mathrm{Bi}(\mathrm{Bi})$, hammarite, pekoite and paděraite. (1) Tsumoite grains within the crystal of tetradymite.

$\mathrm{Pb}_{0.99}\left(\mathrm{Bi}_{2.91} \mathrm{Sb}_{0.02}\right)_{\sum 2.93}\left(\mathrm{~S}_{5.96} \mathrm{Se}_{0.02}\right)_{\sum 5.98}$ (based on total atoms $=11)$, corresponding to the ideal formula $(\mathrm{CuPb}$ $\left.\mathrm{Bi}_{3} \mathrm{~S}_{6}\right)$.

Pekoite rarely occurs as irregular particles of 10 to $30 \mu \mathrm{m}$ in size, intergrown with hammarite in Type-C
(Fig. 4e). The empirical formula is $\mathrm{Cu}_{0.92} \mathrm{~Pb}_{0.84}\left(\mathrm{Bi}_{10.96}\right.$ $\left.\mathrm{Sb}_{0.15}\right)_{\sum 11.11}\left(\mathrm{~S}_{18.26} \mathrm{Se}_{0.04}\right)_{\Sigma 18.30}$ (based on total atoms $=31$ ), corresponding to the the ideal formula $\left(\mathrm{CuPbBi}_{11} \mathrm{~S}_{18}\right)$.

Bismuthinite occurs as irregular grains from 100 to $500 \mu \mathrm{m}$ in size, coexisting with cuprobismutite group 

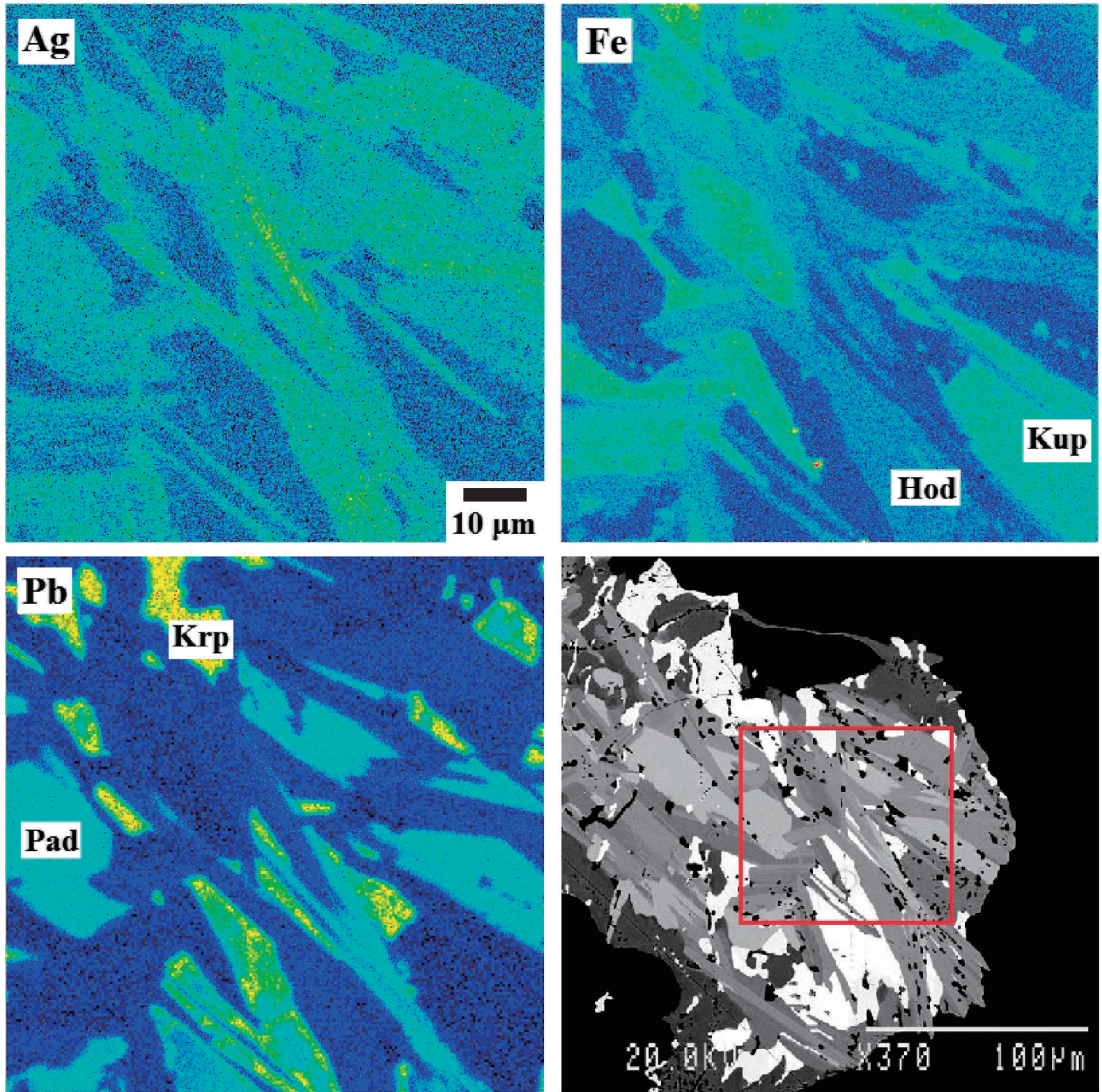

Figure 5. X-ray intensity maps $(\mathrm{Ag} L \alpha, \mathrm{Fe} K \alpha$ and $\mathrm{PbM \alpha})$ of the intergrowths of hodrušhite kupčíkite and paderraite, which correspond to Figure 4c.

minerals, makovickyite and tetradymite (Fig. 4b). The empirical formula is $\mathrm{Cu}_{0.10} \mathrm{~Pb}_{0.08}\left(\mathrm{Bi}_{1.83} \mathrm{Sb}_{0.01}\right)_{\sum 1.84}\left(\mathrm{~S}_{2.96}\right.$ $\left.\mathrm{Se}_{0.01}\right)_{\sum 2.97}$ (based on total atoms $=5$ ), corresponding to the ideal formula $\left(\mathrm{Bi}_{2} \mathrm{~S}_{3}\right)$. This mineral has high contents of $\mathrm{Cu}$ and $\mathrm{Pb}$ (Fig. 3c).

\section{Pb-Bi-S minerals}

Galenobismutite occurs as irregular grains of up to 400 $\mu \mathrm{m}$ in size, as intergrowths with cosalite, hammarite and aikinite (Fig. 4e). The empirical formula is $\mathrm{Pb}_{0.99}\left(\mathrm{Bi}_{1.90}\right.$ $\left.\mathrm{Sb}_{0.07}\right)_{\sum 1.97} \mathrm{~S}_{4.03}$ (based on total atoms $=7$ ), corresponding to the ideal formula $\left(\mathrm{PbBi}_{2} \mathrm{~S}_{4}\right)$
"Cannizzarite" rarely occurs as euhedral to subhedral elongated crystals of $40 \mu \mathrm{m}$ in size within bismuthinite (Fig. 4f). The empirical formula is $\left(\mathrm{Ag}_{0.47} \mathrm{Cu}_{0.31}\right.$ $\left.\mathrm{Fe}_{0.12} \mathrm{~Pb}_{7.23}\right)_{\sum 8.13}\left(\mathrm{Bi}_{9.72} \mathrm{Sb}_{0.27}\right)_{\sum 9.99}\left(\mathrm{~S}_{22.62} \mathrm{Te}_{0.10} \mathrm{Se}_{0.15}\right)_{\sum 22.86}$ (based on total atoms $=41$ ), corresponding to the ideal formula $\left(\mathrm{Pb}_{8} \mathrm{Bi}_{10} \mathrm{~S}_{23}\right)$. Cannizzarite is not a single mineral, but a variable-fit homologous series (Topa et al., 2010), and some different cell-parameters have been reported from two localities, Vulcano, Italy (Topa et al., 2010) and Kudriavy volcano, Russia (Borisov et al., 2012).

Cosalite is the main $\mathrm{Bi}$-sulfosalt of $\mathrm{Pb}-\mathrm{Bi}-\mathrm{S}$ systems in the Obari mine. The mode of occurrence of cosalite from the mine is divided into two types. One occurs as 
large anhedral crystals of 0.1 to $3 \mathrm{~mm}$ in size, coexisting with aikinite, tetradymite, galena and chalcopyrite in (Fig. 4g), and with galenobismutite and the aikinitebismuthinite series (Fig. 4e). The empirical formula is $\left(\mathrm{Ag}_{0.11} \mathrm{Cu}_{0.40}\right)_{\sum 0.51}\left(\mathrm{~Pb}_{1.65} \mathrm{Cd}_{0.01}\right)_{\sum 1.66}\left(\mathrm{Bi}_{1.71} \mathrm{Sb}_{0.20}\right)_{\sum 1.91}\left(\mathrm{~S}_{4.91}\right.$ $\left.\mathrm{Te}_{0.01}\right)_{\sum 4.92}$ (based on total atoms $=9$ ). The obtained unit cell parameters are $a=23.8405(11), b=4.0479(2), c=$ 19.0436 $\AA, V=1837.78 \AA^{3}, Z=8$. Although this mineral is rich in $\mathrm{Ag}$ and $\mathrm{Cu}$ and its chemical composition is similar to neyite, the mineral is identified as cosalite by the unit cell parameters. The crystal structure of $\mathrm{Ag}$ and $\mathrm{Cu}$ rich cosalite has been reported by Topa and Makovicky (2010). The other occurs as irregular grains of 10 to $100 \mu \mathrm{m}$ in size in association with tetradymite and lillianite (Fig. 4h). The empirical formula is $\left(\mathrm{Ag}_{0.01} \mathrm{Cu}_{0.24}\right)_{\sum 0.25}$ $\mathrm{Pb}_{1.84}\left(\mathrm{Bi}_{1.83} \mathrm{Sb}_{0.08}\right)_{\sum 1.91}\left(\mathrm{~S}_{4.97} \mathrm{Te}_{0.01} \mathrm{Se}_{0.01}\right)_{\sum 4.99}$, corresponding to the ideal formula $\left(\mathrm{Pb}_{2} \mathrm{Bi}_{2} \mathrm{~S}_{5}\right)$.

Lillianite occurs as irregular particles from 10 to 20 $\mu \mathrm{m}$ in size, as intergrowths with tetradymite and cosalite (Fig. 4h). The empirical formula is $\left(\mathrm{Ag}_{0.12} \mathrm{Cu}_{0.03}\right)_{\sum 0.15} \mathrm{~Pb}_{2.70}$ $\left(\mathrm{Bi}_{2.05} \mathrm{Sb}_{0.06}\right)_{\sum 2.11}\left(\mathrm{~S}_{6.02} \mathrm{Te}_{0.01} \mathrm{Se}_{0.01}\right)_{\sum 6.04}$ (based on total atoms $=11)$, corresponding to the ideal formula $\left(\mathrm{Pb}_{3} \mathrm{Bi}_{2} \mathrm{~S}_{6}\right)$.

\section{Other Bi-sulfosalts}

Miharaite was orginally reported from the Mihara mine (Sugaki et al., 1980), but the occurrence of this mineral is rare in Japan. This mineral from the Obari mine occurs as irregular grains of 100 to $200 \mu \mathrm{m}$ in size, associated with aikinite, wittichenite, chalcopyrite and tennantite (Fig. 4i). The empirical formula is $\mathrm{Cu}_{4.02} \mathrm{Fe}_{0.99} \mathrm{~Pb}_{1.01} \mathrm{Bi}_{0.95} \mathrm{~S}_{6.03}$ (based on total atoms $=13$ ), corresponding to the ideal formula $\left(\mathrm{Cu}_{4} \mathrm{FePbBiS}_{6}\right)$.

Nuffieldite was first discovered in Japan. This mineral is very rare and occurs as irregular particles from 20 $\mu \mathrm{m}$ in size, coexisting with aikinite (Fig. 4j). The empirical formula is $\mathrm{Cu}_{1.50} \mathrm{~Pb}_{2.00}\left(\mathrm{~Pb}_{0.34} \mathrm{Bi}_{0.34} \mathrm{Sb}_{0.32}\right)_{\sum 1.00} \mathrm{Bi}_{2.00}$ $\left(\mathrm{S}_{7.09} \mathrm{Se}_{0.02}\right)_{\sum 7.11}$ (based on total $\mathrm{Pb}+\mathrm{Bi}+\mathrm{Sb}=5$ ), corresponding to the ideal formula $\mathrm{Cu}_{1.40} \mathrm{~Pb}_{2.00}\left(\mathrm{~Pb}_{0.4} \mathrm{Bi}_{0.40}\right.$ $\left.\mathrm{Sb}_{0.20}\right)_{\sum 1.00} \mathrm{Bi}_{2.00} \mathrm{~S}_{7.00}$. The mineral contains small amounts of $\mathrm{Sb}$, which is an essential element for stabilizing the crystal structure of this mineral (Maurel and Moëlo, 1990).

\section{Bi-tellurides}

Tetradymite is the most common Bi-telluride in the Obari mine and is seen in various $\mathrm{Bi}-$ mineral assemblages. The mode of occurrence of this mineral is divided into two types. One occurs as small irregular particles from 1 to 30 $\mu \mathrm{m}$ in size. The empirical formula is $\left(\mathrm{Cu}_{0.01} \mathrm{~Pb}_{0.01} \mathrm{Bi}_{1.97}\right.$ $\left.\mathrm{Sb}_{0.02}\right)_{\sum 2.01} \mathrm{Te}_{1.93} \mathrm{~S}_{1.06}$ (based on total atoms $=5$ ). The oth- er occurs as large tabular crystals of 0.1 to $2 \mathrm{~mm}$ in size, which has small inclusions of tellurobismuthite, rucklidgeite and tusmoite, accompanied by lillianite and cosalite (Fig. 2f). The empirical formula is $\left(\mathrm{Pb}_{0.03} \mathrm{Bi}_{1.97} \mathrm{Sb}_{0.01}\right)_{\sum 2.01}$ $\mathrm{Te}_{1.91} \mathrm{~S}_{1.07}$. Both tetradymites correspond to the ideal formula $\left(\mathrm{Bi}_{2} \mathrm{Te}_{2} \mathrm{~S}\right)$.

Joséite-B occurs as irregular grains of 40 to $100 \mu \mathrm{m}$ in size, in association with tetradymite and aikinite (Fig. $4 \mathrm{k})$. The empirical formula is $\left(\mathrm{Cu}_{0.05} \mathrm{~Pb}_{0.05} \mathrm{Bi}_{3.89} \mathrm{Sb}_{0.02}\right)_{\sum 4.01}$ $\mathrm{Te}_{1.95} \mathrm{~S}_{1.04}$ (based on total atoms $=7$ ), corresponding to the ideal formula $\left(\mathrm{Bi}_{4} \mathrm{Te}_{2} \mathrm{~S}\right)$.

Tsumoite was first discovered from the Tsumo mine (Shimazaki and Ozawa, 1978), but the occurrence of this mineral is rare in Japan. This mineral occurs as irregular grains of 1 to $20 \mu \mathrm{m}$ in size within tetradymite (Figs. $2 \mathrm{f}$ and 4l). The empirical formula is $\left(\mathrm{Pb}_{0.01} \mathrm{Bi}_{1.00} \mathrm{Sb}_{0.01}\right)_{\sum 1.02}$ $\mathrm{Te}_{0.98}$ (based on total atoms $=2$ ), corresponding to the ideal formula (BiTe).

Rucklidgeite rarely occurs as small inclusions from 1 to $10 \mu \mathrm{m}$ in size of tetradymite. The empirical formula is $\quad\left(\mathrm{Ag}_{0.02} \mathrm{Cu}_{0.03} \mathrm{~Pb}_{0.02} \mathrm{Bi}_{2.96} \mathrm{Sb}_{0.03}\right)_{\sum 3.06}\left(\mathrm{Te}_{3.90} \mathrm{~S}_{0.03}\right)_{\sum 3.93}$ (based on total atoms $=7$ ), corresponding to the ideal formula $\left[(\mathrm{Pb}, \mathrm{Bi})_{3} \mathrm{Te}_{4}\right]$. This mineral has a low- $\mathrm{Pb}$ content. Low-Pb rucklidgeite has been reported from several localities such as the Larga-Fata Baii field, Romania (Cook and Ciobanu, 2004).

Tellurobismuthite sometimes occurs as irregular grains of 1 to $30 \mu \mathrm{m}$ in size within tetradymite. The empirical formula is $\left(\mathrm{Ag}_{0.02} \mathrm{Bi}_{1.96} \mathrm{Sb}_{0.02}\right)_{\sum 2.00}\left(\mathrm{Te}_{2.99} \mathrm{~S}_{0.01}\right)_{\sum 3.00}$ (based on total atoms $=5$ ), corresponding to the ideal formula $\left(\mathrm{Bi}_{2} \mathrm{Te}_{3}\right)$.

\section{BI-SULFOSALT AND BI-TELLURIDE ASSEMBLAGES}

$\mathrm{Bi}$-sulfosalts and $\mathrm{Bi}$-tellurides from the Obari mine are divided into five assemblage types; (1) Type-A: wittichenite and aikinite-dominant assemblage, (2) Type-B: cuprobismutite group mineral-bearing assemblage, (3) Type-C: galenobismutite-bearing assemblage, (4) Type$\mathrm{D}$ : Native Bi-bearing assemblage and (5) Type-E: Bi-telluride-dominant assemblage. Among these assemblages, Type- $\mathrm{A}$ is the most common and Type-B to Type-E are rare in the studied samples.

(1) Type-A wittichenite and aikinite-dominant assemblage: This assemblage is composed of aikinite (Fig. 2a) and wittichenite (Fig. 2b), subordinate cosalite and tetradymite and trace amounts of miharaite. These $\mathrm{Bi}$ minerals are accompanied by chalcopyrite, bornite, tetrahedrite and tennantite and minor sphalerite, galena, molybdenite, electrum, hessite, arsenopyrite and pyrite.

(2) Type-B cuprobismutite group mineral-bearing assem- 
blage: This assemblage is composed of cuprobismutite group minerals (cuprobismutite, hodrušhite, kupčíkite and paderaite), makovickyite, cupromakovickyite and aikinite-bismuthinite series (bismuthinite, krupkaite and aikinite) accompanied by emplectite and tetradymite (Fig. $4 b$ ), and trace amounts of nuffieldite and cannizzarite. Chalcopyrite and small amounts of molybdenite occur as other ore minerals in the assemblage.

(3) Type-C galenobismutite-bearing assemblage: This assemblage is composed of galenobismutite and cosalite, coexisting with small amounts of tetradymite and aikinite-bismuthinite series (friedrichite, hammarite lindströmite and pekoite) (Fig 4e).

(4) Type-D native Bi-bearing assemblage: This assemblage is composed of aikinite, accompanied by minor native $\mathrm{Bi}$, joséite- $\mathrm{B}$, tetradymite, paderaite, aikinite-bismuthinite series (aikinite, hammarite and pekoite) and emplectite (Fig. 4k). Native Bi is very rare in the Obari mine. (5) Type-E Bi-telluride-dominant assemblage: This assemblage is composed of tetradymite tellurobismuthite, tsumoite and rucklidgeite, in association with subordinate lilianite and cosalite (Fig. 2f). Chalcopyrite and galena sometimes occur in the assemblage.

\section{DISCUSSION}

\section{Identification of cuprobismutite group minerals using minor components}

Cuprobismutite group minerals from the Obari mine are distinguished by the amounts of the minor components in each mineral. When minor components of each cuprobismutite group mineral are plotted on a ternary diagram (Fig. 6), the amounts of minor components (Ag, Fe and $\mathrm{Pb}$ ) in the minerals are consistent with the range shown by Topa et al. (2003a) and Topa and Makovicky (2006) except for cuprobismutite. Cuprobismutite from the mine is beyond the range, because it contains small amounts of $\mathrm{Fe}$ and is poor in $\mathrm{Pb}$. However, this mineral is the most Ag-rich among the minerals and $\mathrm{Fe}$-bearing cuprobismutite has been reported from other localities as discussed later. Therefore, the Fe-bearing cuprobismutite from the Obari mine is possibly identified as cuprobismutite. Consequentry, it is considered that cuprobismutite group minerals from the mine are generally consistent with the characteristics of the minor components indicated by Topa et al. (2003a) and Topa and Makovicky (2006). In addition, the distribution of the minor components of hodrušhite, kupčíkite and paděraite has been supported by X-ray intensity mapping (Fig. 5).

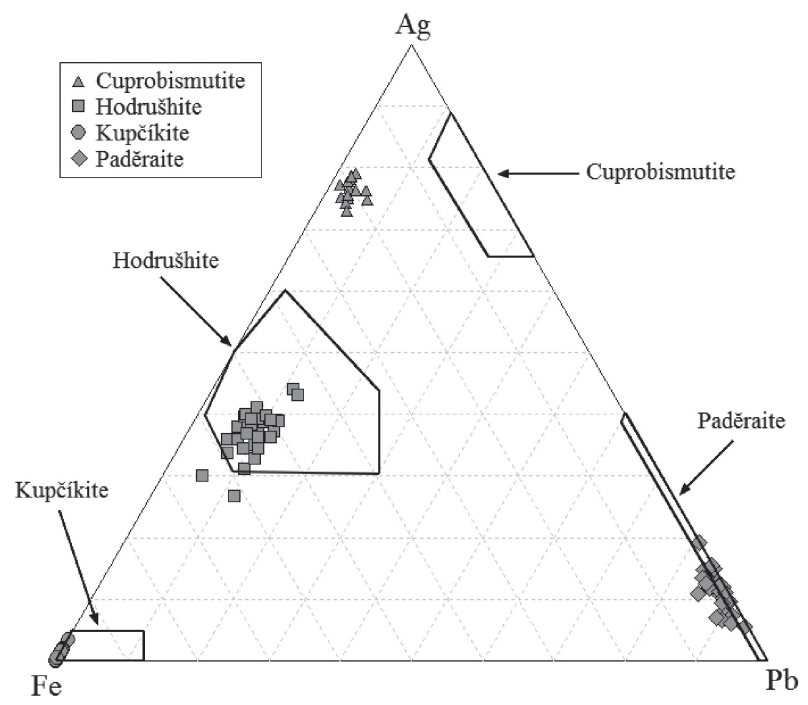

Figure 6. Relations of minor components $(\mathrm{Ag}, \mathrm{Pb}$ and $\mathrm{Fe})$ in cuprobismutite group minerals. The range of minor components has been shown by Topa et al. (2003a) and Topa and Makovicky (2006).

\section{Characteristics of the chemical composition of cupro- bismutite group minerals}

In comparison with other localities and the ideal formula, cuprobismutite has a small amount of Fe. Fe-bearing cuprobismutite has been reported in previous studies. It is considered that the origin of the $\mathrm{Fe}$ is derived from $\mathrm{Fe}-$ bearing minerals as follows. The mineral from the Čierna Lehota, Slovakia contains small inclusions of pyrite (Pršek et al., 2005) and from the Szklarska Poręba quarry, Poland contains small lamellae of hodrushite which are intergrown with cuprobismutite (Pieczka and Gołebiowska, 2012). Cuprobismutite from the Obari mine occurs as small grains and is adjacent to a Fe-bearing undetermined secondary Bi-mineral (Fe 2.6-6.0 wt\%). The origin of $\mathrm{Fe}$ in cuprobismutite might be derived from the Fe-bearing secondary mineral.

Hodrušhite from the mine is poor in $\mathrm{Bi}$ and rich in $\mathrm{Cu}$, compared with other localities and the ideal formula (Fig. 7). A mineral similar to the one in this mine has been reported only from the Swartberg deposit, South Africa (Topa et al., 2003a). The crystal structure analysis of hodrušhite from the Swartberg indicated that the $\mathrm{Bi}$ site is partly replaced by $\mathrm{Cu}$ (Topa et al., 2003a). It is considered that hodrušhite from this mine is rich in $\mathrm{Cu}$ by the substitution of $\mathrm{Bi} \rightarrow \mathrm{Cu}$ as well.

Kupčíkite from the mine is poor in $\mathrm{Bi}$ and rich in $\mathrm{Cu}$ and Fe (Fig. 7), and contains trace amounts of $\mathrm{Zn}$. This mineral has a similar composition to that reported from the Szklarska Poręba quarry (Pieczka and Gołębiowska, 2012). The substitutions of $\mathrm{Fe} \rightarrow \mathrm{Zn}$ and $\mathrm{Bi} \rightarrow \mathrm{Cu}$ were 


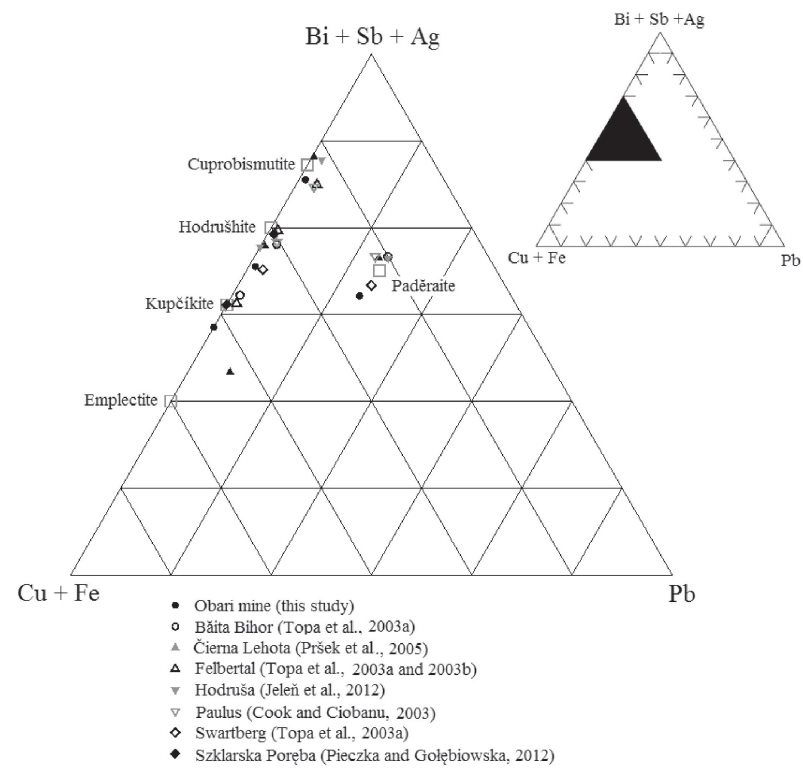

Figure 7. $(\mathrm{Bi}+\mathrm{Sb}+\mathrm{Ag})-(\mathrm{Cu}+\mathrm{Fe})-\mathrm{Pb}$ ternary diagram of cuprobismutite group minerals from the Obari mine and other localities.

pointed out by Pieczka and Gołębiowska (2012). Although crystal structure analysis has not been performed, it is assumed that kupčíkite from the Obari mine has similar substitutions as well as that suggested by Pieczka and Gołębiowska (2012).

Paderraite from the mine is rich in $\mathrm{Cu}$, compared to other localities and the ideal formula (Fig. 7). $\mathrm{Cu}$-rich paděraite was also reported from the Swartberg deposit (Topa and Makovicky, 2006). This mineral has an X site. In the $\mathrm{X}$ site, $\mathrm{Bi}$ substitutes for $\mathrm{Ag}$ and $\mathrm{Cu}$, as shown by the crystal structure analysis of Topa and Makovicky (2006). It is considered that paderraite from the Obari mine is rich in $\mathrm{Cu}$ by the inverse substitution, $\mathrm{Bi} \rightarrow$ $\mathrm{Cu}$, at the $\mathrm{X}$ site as well.

\section{Genetic environment of cuprobismutite group miner- als}

Cuprobismutite group minerals occur in deposits which may be formed at high temperature such as Alpine-type, skarn, pegmatite and xenothermal-type deposits. The homogenization temperature of fluid inclusions in quartz from the Felbertal deposit of the Alpine-type, Austria was shown to be $260-360{ }^{\circ} \mathrm{C}$ (Schenk et al., 1990). In the Hodruša-Hámre xenothermal-type deposit, Slovakia, the homogenization temperature of fluid inclusions in quartz associated with $\mathrm{Bi}$-minerals was indicated to be 300-345 ${ }^{\circ} \mathrm{C}$, and $\mathrm{Bi}-$ minerals have been found at a deeper level in the deposit (Jeleň et al., 2012). Cuprobismutite group minerals and makovickyite also have been discov- ered from the deepest level in the Paulus skarn deposit, Romania (Cook and Ciobanu, 2003). Moreover, synthetic cuprobismutite group minerals reached a stable phase above $300{ }^{\circ} \mathrm{C}$ in the phase equilibrium experiment (Sugaki et al., 1981a). The homogenization temperature of the fluid inclusion in quartz from the Obari mine ranges from 310 to $390{ }^{\circ} \mathrm{C}$ (Izumino and Nakashima, 2011). Therefore, cuprobismutite group minerals from the mine have been formed at a temperature higher than $300{ }^{\circ} \mathrm{C}$.

\section{Comparison of the $\mathrm{Bi}$ minerals in other deposits from Japan}

Many kinds of Bi-sulfosalts and Bi-tellurides such as the cuprobismutite group minerals have been found in the Obari mine in this study. The total number of species of Bi minerals reaches more than 20. No deposit has been known with more Bi-minerals than the Obari mine in Japan. The Bi-sulfosalts of this mine are composed of $\mathrm{Cu}, \mathrm{Pb}, \mathrm{Bi}$ and $\mathrm{S}$ as major elements and $\mathrm{Ag}, \mathrm{Fe}, \mathrm{Sb}$ and $\mathrm{Se}$ as minor elements, though $\mathrm{Ag}$-dominant $\mathrm{Bi}$-sulfosalts such as matildite were not observed at this locality. Bi minerals from this mine are classified into four types; $\mathrm{Cu}-\mathrm{Bi}-\mathrm{S}$ minerals, aikinite-bismuhinite series $(\mathrm{Cu}-\mathrm{Pb}-$ $\mathrm{Bi}-\mathrm{S}$ minerals), $\mathrm{Pb}-\mathrm{Bi}-\mathrm{S}$ minerals and $\mathrm{Bi}$-tellurides.

Emplectite and wittichenite, belonging to the $\mathrm{Cu}^{-}$ $\mathrm{Bi}-\mathrm{S}$ minerals have been reported from $\mathrm{Cu}$ deposits such as the Mihara (Sugaki et al., 1980) and the Imooka mines (Sugaki et al., 1975; Kitakaze et al., 2013) in which primary bornite occurs. In addition, miharaite and the eutectic intergrowths of bornite-chalcopyrite-wittichenite are known to occur at both mines as well as at the Obari mine. The occurrences of emplectite, wittichenite, miharaite and bornite reflect $\mathrm{Cu}$-dominant mineralization. $\mathrm{Pb}$ $\mathrm{Bi}-\mathrm{S}$ minerals were not found in either mine, whereas they are common in the Obari mine.

The aikinite-bismuthinite series were discovered in the $\mathrm{Cu}-\mathrm{Bi}-\mathrm{W}-\mathrm{Co}-\mathrm{As}$ deposits such as the Sasanami mine, hosted in the Hoben granitic complex (Nakashima et al., 1981). Pb-Bi-S minerals such as cannizzarite and cosalite were also found, but $\mathrm{Cu}-\mathrm{Bi}-\mathrm{S}$ minerals such as wittichenite and primary bornite were not present. The series from the deposits, as well as from the Obari mine, are associated with chalcopyrite and $\mathrm{Pb}$-bearing minerals such as galena or $\mathrm{Pb}-\mathrm{Bi}-\mathrm{S}$ minerals. The occurrences of aikinite-bismuthinite series reflect $\mathrm{Cu}$ and $\mathrm{Pb}$ mineralization.

$\mathrm{Pb}-\mathrm{Bi}-\mathrm{S}$ minerals such as cosalite and lillianite have been reported in many type deposits in Japan such as the $\mathrm{Cu}-\mathrm{Bi}-\mathrm{W}-\mathrm{Co}-\mathrm{As}$ vein-type deposits hosted in the Hoben granitic complex (Nakashima et al., 1981), the Kamioka (Mariko et al.,1996) and the Nakatatsu (Mariko, 1981) 
$\mathrm{Zn}-\mathrm{Pb}$ skarn deposits, the Agenosawa $\mathrm{Cu}-\mathrm{Pb}-\mathrm{Zn}$ veintype deposit in the green tuff region (Nedachi et al., 1973), the Suzuyama Sn vein-type deposit (Nedachi et al., 1990) and the Otome Mo-W vein-type deposit (Tsunoda and Shimizu, 1995). Like these deposits, the $\mathrm{Pb}-\mathrm{Bi}^{-}$ $\mathrm{S}$ minerals are associated with galena in the Obari mine. The occurrences of $\mathrm{Pb}-\mathrm{Bi}-\mathrm{S}$ minerals and galena reflect $\mathrm{Pb}$ mineralization.

Bi-tellurides such as tetradymite and tellurobismuthite have been reported in many types of $\mathrm{Au}-\mathrm{Bi}-\mathrm{Te}$ deposits such as the Tsumo (Sugaki et al., 1981b), the Sannotake (Kato and Sakurai, 1962) and the Shin-Kiura (Miyahisa, 1962) skarn deposits and the Oya vein-type deposit (Yamaoka, 1981). Bi-tellurides are associated characteristically with electrum in these deposits and $\mathrm{Te}$ is closely related with $\mathrm{Au}-\mathrm{Bi}$ mineralization. In the Obari mine, electrum sometimes occurs with aikinite, tetradymite and chalcopyrite (Fig. 2e) and the Au grade of ores is Au $200 \mathrm{~g} / \mathrm{t}$ (Shimazu et al., 1961), which is particularly high. The occurrences of Bi-tellurides reflect $\mathrm{Au}-\mathrm{Bi}$ mineralization.

$\mathrm{Ag}-\mathrm{Bi}-\mathrm{S}$ and $\mathrm{Ag}-\mathrm{Pb}-\mathrm{Bi}-\mathrm{S}$ minerals, such as matildite and pavonite, have not been found in the Obari mine, but have been reported from the $\mathrm{Sn}$-polymetallic deposits such as the Ikuno deposit (Shimizu and Kato, 1996; Shimizu et al., 1998) and the Suttsu deposit (Ono et al., 2004). Ag major minerals such as acanthite and Bi-selenides also have been found in Sn-polymetallic deposits. Exceptionally, makovickyite, belonging to pavonite homologous minerals, occurs in the Obari mine, but this mineral indicates $\mathrm{Cu}>\mathrm{Ag}$ compared to the ideal formula (Izumino et al., 2013). In addition, Ag major minerals such as acanthite were not observed. On the other hand, benjaminite and pavonite, belonging to the pavonite homologous minerals, from the Ikuno mine indicate compositions close to the ideal formula and are $\mathrm{Cu}$-free. Therefore, $\mathrm{Ag}-\mathrm{Bi}-\mathrm{S}$ minerals reflect $\mathrm{Ag}$ mineralization and it is considered that such minerals were not formed in the Obari mine due to the lack of Ag mineralization.

In conclusion, the Obari mine is characterized by the occurrences of $\mathrm{Cu}$-Bi-sulfosalts, reflecting the $\mathrm{Cu}$-dominant mineralization. Moreover, since this mineralization is associated with small amounts of $\mathrm{Au}-\mathrm{Te}$ and $\mathrm{Pb}$, many kinds of Bi-sulfosalts and Bi-tellurides were formed, compared to those of other deposits in Japan. On the other hand, $\mathrm{Ag}-\mathrm{Bi}-\mathrm{S}$ minerals were not formed because of a lack of $\mathrm{Ag}$ in the mineralization unlike Sn-polymetallic type deposits.

\section{ACKNOWLEDGMENTS}

Special thanks are due to Mr. Jun-Ichi Igarashi for pro- viding the ore specimens from the Obari mine and Prof. Richard W. Jordan of Yamagata University for improving the English manuscript. We thank Dr. Ritsuro Miyawaki, an anonymous reviewer and Associated Editor Dr. T. Mikouchi for their constructive and editorial comments.

\section{SUPPLEMENTARY MATERIAL}

Color version of Figures 2 is available online from http:// japanlinkcenter.org/DN/JST.JSTAGE/jmps/140129.

\section{REFERENCES}

Agency of Natural Resources and Energy (1982) Report of regional geological survey of Uetsu Area (I). pp. 164 (in Japanese).

Borisov, S.V., Pervukhina, N.V., Magarill, S.A., Kuratieva, N.V., Bryzgalov, I.A., Mozgova, N.N. and Chaplygin, I.V. (2012) The crystal structure of cannizzarite from Kudriavy volcano, Iturup Island, Kuriles, Russia. Canadian Mineralogist, 50, 387-395.

Bruker (1999) SMART and SAINT-Plus. Versions 6.01. Bruker AXS Inc., Madison, Wisconsin, USA.

Cook, N.J. and Ciobanu, C.L. (2003) Lamellar minerals of the cuprobismutite series and related paděraite: a new occurrence and implications. Canadian Mineralogist, 41, 441-456.

Cook, N.J. and Ciobanu, C.L. (2004) Bismuth tellurides and sulphosalts from the Larga hydrothermal system, Metaliferi Mts, Romania: paragenesis and genetic significance. Mineralogical Magazine, 68, 301-321.

Hillebrand, W.F. (1884) On an interesting variety of löllingite and other minerals. American Journal of Science, 27, 349-358.

Ishihara, S., Sasaki, A. and Terashima, S. (1983) Granitoids and mineralization in the Uetsu area, Japan. Bulletin of the Geological Survey of Japan, 34, 11-26 (in Japanese with English abstract).

Izumino, Y. and Nakashima, K. (2011) Au-Ag-Cu-Bi mineralization in the Obari mine, Yamagata Prefecture, Japan. Abstract of the $61^{\text {th }}$ Meeting of the Society of Resource Geology, P-10 (in Japanese).

Izumino, Y., Nakashima, K. and Nagashima, M. (2013) Makovickyite and cupromakovickyite from the Obari mine, Yamagata Prefecture, Japan. Journal of Mineralogical and Petrological Sciences, 108, 94-100.

Jeleň, S., Pršek, J., Kovalenker, V., Topa, D., Sejkora, J., Števko, M. and Ozdín, D. (2012) Bismuth sulfosalts of the cuprobismutite, pavonite and aikinite series from the Rozália mine, Hodruša-Hámre, Slovakia. Canadian Mineralogist, 50, 325340 .

Kato, A. and Sakurai, K. (1962) Tetradymite from Sannotake, Fukuoka Prefectute. Journal of the Mineralogical Society of Japan, 5, 324-334 (in Japanese).

Kitakaze, A., Ito, H. and Komatsu, R. (2013) Miharaite from the Imooka mine, Okayama Prefecture, Japan and its thermal stability. Center for Northeast Asian Studies, 17, 139-150 (in Japanese with English abstract).

Koděra, M., Kupčík, V. and Makovicky, E. (1970) Hodrushite - a new sulfosalt. Mineralogical Magazine, 37, 641-648.

Makovicky, E. (1989) Modular classification of sulphosalts - current status definition and application of homologous series. Neues Jahrbuch für Mineralogie Abhandlungen, 160, 269- 
297.

Mariko, T. (1981) Silver distribution and silver-bearing minerals in the Nakayama and Hitokata ore deposits. Mining Geology Special Issue, 10, 159-174 (in Japanese with English abstract).

Mariko, T., Kawada, M., Miura, M. and Ono, S. (1996) Ore formation processes of the Mozumi skarn-type $\mathrm{Pb}-\mathrm{Zn}-\mathrm{Ag}$ deposit in the Kamioka mine, Gifu Prefecture, Central Japan - A mineral chemistry and fluid inclusion study. Resource Geology, 46, 337-354.

Maurel, C. and Moëlo, Y. (1990) Systhese de la nuffieldite dans le systeme $\mathrm{Bi}-\mathrm{Pb}-\mathrm{Sb}-\mathrm{Cu}-\mathrm{S}$. Canadian Mineralogist, 28, 745749.

Miyahisa, M. (1962) Gold-tellurium-bismute-arsenic ore of the Shin-Kiura tin mine, Kyushu, Japan. Mining Geology, 12, 317-323 (in Japanese with English abstract).

Mumme, W.G. and Žák, L. (1985) Paděraite, $\mathrm{Cu}_{5.9} \mathrm{Ag}_{1.3} \mathrm{~Pb}_{1.6} \mathrm{Bi}_{11.2}$ $\mathrm{S}_{22}$, a new mineral of the cuprobismutite - hodrushite group. Neues Jahrbuch für Mineralogie Monatshefte, 1985, 557-567.

Nagashima, M., Armbruster, T., Izumino, Y. and Nakashima, K. (2013) Crystal chemistry of a $\mathrm{Cu}$ isotype of makovickyite from the Obari mine, Yamagata Prefecture, Japan. Neues Jahrbuch für Mineralogie Abhandlungen, 191, 75-81.

Nakashima, K., Watanabe, M. and Soeda, A. (1981) Mineralogy of the $\mathrm{Cu}-\mathrm{Bi}-\mathrm{W}-\mathrm{Co}-\mathrm{As}-\mathrm{S}$ mineralization associated with the Hobenzan granitic complex, Yamaguchi Prefecture, southwest Japan. Journal of the Japanese Association of Mineralogists, Petrologists and Economic Geologists, 76, 1-16.

Nedachi, M., Takeuchi, T., Yamaoka, K. and Taniguchi, M. (1973) $\mathrm{Bi}-\mathrm{Ag}-\mathrm{Pb}-\mathrm{S}$ minerals from Agenosawa mine, Akita Prefecture, northeastern Japan. Science reports of the Tohoku University. Ser. 3, Mineralogy, petrology, economic geology, 12, 69-80.

Nedachi, M., Urashima, Y. and Enjoji, M. (1990) Bi-Pb-Ag-S minerals from tin ore deposits in the Outer Zone of Southwest Japan. Professor Yukitoshi Urashima Commemoration Volume on the Occasion of his Retierment, 247-253.

Ono, S., Hirai, K., Matsueda, H. and Kabashima, T. (2004) Polymetallic mineralization at the Suttsu vein-type deposits, southwestern Hokkaido, Japan. Resource Geology, 54, 453464.

Pieczka, A. and Gołębiowska, B. (2012) Cuprobismutite homologues in granitic pegmatites from Szklarska Poręba, Karkonosze massif, southwestern Poland. Canadian Mineralogist, 50, 313-324.

Pršek, J., Mikuš, T., Makovicky, E. and Chovan, M. (2005) Cuprobismutite, kupčíkite, hodrušhite and associated sulfosalts from the black shale hosted Ni-Bi-As mineralization at Čierna Lehota, Slovakia. European Journal of Mineralogy, 17, 155-162.

Schenk, P., Höll, R., Ivanova, G.F., Naumov, V.B. and Kopneva, L.A. (1990) Fluid inclusion studies of the Felbertal scheelite deposit. Geologische Rundschau, 79, 451-466.

Shimazaki, H. and Ozawa, T. (1978) Tsumoite, BiTe, a new mineral from the Tsumo mine, Japan. American Mineralogist, 63, 1162-1165.

Shimazu, M., Koseki, K. and Obi, I. (1961) Uraniferous ore deposits in Asahi and Obari areas, Yamagata Prefecture. Reports of the Geological Survey of Japan, 190, 173-183 (in Japanese with English abstract).

Shimizu, M. and Kato, A. (1996) Pavonite from the Ikuno mine, Hyogo Prefecture, Japan. Canadian Mineralogist, 34, 13231327.
Shimizu, M., Kato, A. and Matsuyama, F. (1998) Two Se-bearing $\mathrm{Ag}-\mathrm{Bi}$ sulphosalts, benjaminite and matildite from the Ikuno deposits, Hyogo prefecture, Japan - $\mathrm{Au}-\mathrm{Ag}$, mineralization in polymetallic zone. Resource Geology, 48, 117-124.

Sugaki, A (1949a) Thermal studies on the lattice intergrowths of chalcopyrite and klaprothite in bornite from Obari mine, Yamagata Pref (1). Journal of the Japanese Association of Mineralogists, Petrologists and Economic Geologists, 33, 85-91 (in Japanese).

Sugaki, A (1949b) Thermal studies on the lattice intergrowths of chalcopyrite and klaprothite in bornite from Obari mine, Yamagata Pref (2). Journal of the Japanese Association of Mineralogists, Petrologists and Economic Geologists, 33, 109-118 (in Japanese).

Sugaki, A., Shima, H. and Kitakaze, A. (1974) Study on chemical composition of mineral in the system $\mathrm{Cu} \cdot \mathrm{Bi} \cdot \mathrm{S}$ : (1) wittichenite (klaprothite). Journal of the Japanese Association of Mineralogists, Petrologists and Economic Geologists, 69, 3243 (in Japanese with English abstract).

Sugaki, A., Shima, H. and Kitakaze, A. (1975) Study on chemical composition of mineral in the system $\mathrm{Cu} \cdot \mathrm{Bi} \cdot \mathrm{S}$ : (2) wittichenite and emplectite from Daniel and Imooka mines. Professor Tsunehiko Takeuchi Memorial Volume on the occasion of his retirement, 73-90 (in Japanese with English abstract).

Sugaki, A., Shima, H. and Kitakaze, A. (1980) Miharaite, $\mathrm{Cu}_{4} \mathrm{Fe}$ $\mathrm{PbBiS}_{6}$, a new mineral from the Mihara mine, Okayama, Japan. American Mineralogist, 65, 784-788.

Sugaki, A., Kitakaze, A. and Hayashi, T. (1981a) Synthesis of minerals in the $\mathrm{Cu}-\mathrm{Fe}-\mathrm{Bi}-\mathrm{S}$ system under hydrothermal condition and their phase relations. Bulletin de Mineralogie, 104, 484495.

Sugaki, A., Soeda, A., Shima, H., Kitakaze, A., Hirowatari, F., Mariko, T. and Takeno, S. (1981b) Ore deposits and minerals of the pyrometasomatic deposit of the Tsumo mine, with special reference to the Maruyama deposit. Mining Geology Special Issue, 9, 89-144 (in Japanese with English abstract).

Takaoka, H. (1969) Syenitization of granodiorite and Bi-Te-Au$\mathrm{Ag}-\mathrm{Cu}$ mineralization in the Obari mine, Yamagata, Prefecture. Kobutsu Kenkyu (Mineral Study), 2, 5-14 (in Japanese with English abstract).

Topa, D., Makovicky, E. and Balić-Žunić, T. (2003a) Crystal structures and crystal chemistry of members of the cuprobismutite homologous series of sulfosalts. Canadian Mineralogist, 41, 1481-1501.

Topa, D., Makovicky, E., Balić-Žunić, T. and Paar, W.H. (2003b) Kupčíkite, $\mathrm{Cu}_{3.4} \mathrm{Fe}_{0.6} \mathrm{Bi}_{5} \mathrm{~S}_{10}$, a new sulfosalt from Felbertal, Austria, and its crystal structure. Canadian Mineralogist, 41, 1155-1166.

Topa, D. and Makovicky, E. (2006) The crystal structure of paděraite, $\mathrm{Cu}_{7}\left(\mathrm{X}_{0.33} \mathrm{~Pb}_{1.33} \mathrm{Bi}_{11.33}\right)_{13} \mathrm{~S}_{22}$, with $\mathrm{X}=\mathrm{Cu}$ or $\mathrm{Ag}$ : new data and interpretation. Canadian Mineralogist, 44, 481-495.

Topa, D. and Makovicky, E. (2010) The crystal chemistry of cosalite based on new electron-microprobe data and single-crystal determinations of the structure. Canadian Mineralogist, 48, 1081-1107.

Topa, D., Makovicky, E. and Dittrich, H. (2010) The crystal structure of $7 \mathrm{H}: 12 \mathrm{Q}$ cannizzarite from Vulcano, Italy. Canadian Mineralogist, 48, 483-495.

Tsunoda, K. and Shimizu, M. (1995) Mineralization of the Suehiro vein of the Otome deposit, Yamanashi Prefecture, Japan. Resource Geology, 45, 111-120 (in Japanese with English abstract). 
Watanabe, M. (1937) Geology and ore deposits of Obari and Hongo mines, Yamagata Prefecture, Japan; especially mineral paragenesis of copper and copper-bismuth sulfide (1). Journal of the Japanese Association of Mineralogists, Petrologists and Economic Geologists, 18, 211-222 (in Japanese).

Watanabe, M. (1938a) Geology and ore deposits of Obari and Hongo mines, Yamagata Prefecture, Japan; especially mineral paragenesis of copper and copper-bismuth sulfide (2). Journal of the Japanese Association of Mineralogists, Petrologists and Economic Geologists, 19, 27-32 (in Japanese).

Watanabe, M. (1938b) Geology and ore deposits of Obari and Hongo mines, Yamagata Prefecture, Japan; especially mineral paragenesis of copper and copper-bismuth sulfide (3). Journal of the Japanese Association of Mineralogists, Petrologists and Economic Geologists, 19, 70-80 (in Japanese).

Watanabe, M. (1938c) Wittichenite from Obari mine, Yamagata Prefecture, Japan (Preliminary Report). Journal of the Japanese Association of Mineralogists, Petrologists and Economic Geologists, 20, 184-188 (in Japanese).
Watanabe, M. (1951) Lattice and graphic intergrowth of some copper minerals from the Obari mine, Japan. Science reports of the Tohoku University. Ser. 3, Mineralogy, petrology, economic geology, 4, 1-10.

Yamaoka, K. (1981) Native gold from Omine (Nippo), Oya and Owashi mines - On the composition of gold from the contactmetasomatic and fissure-filling ore deposits in the Kitakami mountains. Mining Geology Special Issue, 10, 151-158 (in Japanese with English abstract).

Yauchi, K., Inoue, T. and Ohguchi, T. (1973) Late Cretaceous Tagawa acidic rocks in the Asahi Mountains, northeast Japan. Journal of Geological Society Japan, 79, 11-22 (in Japanese with English abstract).

Manuscript received January 29, 2014

Manuscript accepted June 23, 2014

Published online July 23, 2014

Manuscript handled by Takashi Mikouchi 